\title{
The Role of the Teacher in Madrasah Ibtidaiyah to Manage Class Towards Child-Friendly
}

\author{
*Zuri Pamuji 1,a \\ ${ }^{1}$ UIN Prof KH Saifuddin Zuhri Purwokerto, Banyumas, Jawa Tengah, Indonesia \\ Email: akuzuri@gmail.com ${ }^{\mathrm{a}}$
}

\begin{abstract}
:
Teacher is the central figure to manage the class towards a child friendly. The management of child-friendly classes in this case is all effort of the teacher in creating and maintaining optimal conditions for the learning process to occur while still paying attention to the protection of the growth and development of the student's potential from acts of violence and discrimination so as to achieve the expected learning objectives. In this regard, child-friendly classroom management patterns related to the role of teachers need to be continuously developed, because they are very strategic in supporting the development of the potential of students. This study aims to map the role of the teacher conceptually related to classroom management towards being child-friendly, sourced from various appropriate literature sources. The research results can be described as follows: first, teachers need to manage students which include enforcing rules in class, providing age-appropriate guidance for students, controlling the course of the learning process. Second, the teacher needs to manage the physical classroom, which includes arranging the seating position of the teacher and students as well as the classroom furniture. Meanwhile, the success of MI teachers in managing classes to become child-friendly classes cannot be separated from the support of all stakeholders in the school.
\end{abstract}

Keywords: Teacher, Madrasah Ibtidaiyah, Classroom Management, Child-friendly

How to cite this article:

Pamuji, Z. (2022). The role of the teacher in madrasah ibtidaiyah to manage class towards child friendly. Mitra PGMI: Jurnal Kependidikan MI, 8(1), 37-49. https://doi.org/10.46963/mpgmi.v8i1.371

\section{Informasi Artikel}

\section{* Corresponding author:}

akuzuri@gmail.com

DOI:

https://doi.org/ 10.46963/mpgmi.v8i1.371
Histori Artikel:

Diterima : 16/07/2021

Direvisi : $22 / 01 / 2022$

Diterbitkan : 31 / $01 / 2022$

\section{INTRODUCTION}

Education is a dynamic and important process in human life. This is due to several reasons, namely: first, education is a basic right for every human being, as listed in the Universal Declaration of Human Rights (UDHR) (Arinanto, 2001). Because it is a basic right, if it is not fulfilled it will have a negative impact on the individual concerned. Second, with education, everyone will have the opportunity to manage and develop their talent optimally (Yahya, 2007). Third, technological advances is something that cannot be avoided in life and it will run in accordance with scientific advances (Prasetyono, 2018). So, education becomes a main strategic to respond effectively and efficiently to the development of science and technology. 
Because of the importance of education, in the context of Indonesia base on regulation, education is a conscious and planned effort to create a learning atmosphere and learning process so that students actively develop their potential to have religious spiritual strength, self-control, personality, intelligence, good character, and skills needed by themselves, society, nation and state (UndangUndang Sistem Pendidikan Nasional, 2003). This definition of education is followed by the opportunity for each student to develop their talent through the learning process available at certain paths, levels, and types of education. From this explanation, it shows that the state is trying to guarantee everyone to get best quality education services according to their age and talent.

As an effort to realize best quality educational services, of course this is not the duty of only one part, for example educational institutions or schools, but is an duty for every stakeholder of educational institutions. Because if it is only the duty of only one part, it will be difficult to realize best quality education services or in other words it will be very difficult to be realized. Among the stakeholders in educational institutions, especially schools, include: the government through the District/City Education Office/Ministry of Religion, parents/guardians of students, teachers, the community, and the private sector. Good synergy from each of these stakeholders will certainly be able to have a significant impact in realizing best quality education services.

One of the parties directly involved in the education process from these several stakeholders, especially schools, is an educator or teacher. The term teachers based on regulation, are professional educators with the main job of educating, teaching, guiding, directing, training, assessing, and evaluating students in early childhood education through formal education, elementary, junior and senior high school (UU Nomor 14 Tahun 2005). So, teachers should make various efforts to provide the best service for students in participating on learning process, because teacher is the central figure in the learning process on classroom.

One of the efforts from the teachers is manage the classroom well. The reason from this effort is to make the students feeling happy and avoiding the afraid and threatened during the learning process. In addition, if the teacher can manage the classroom well, it will minimize the occurrence of actions that can harm the rights of every citizen in the class, both for students and teachers themselves, one of which is violence in the classroom or during the learning process.

This is very important and urgent to do because the phenomenon of violence in the school or in the learning process still occurs. For example: first, an incident that occurred where an unscrupulous teacher with the initials EP allegedly hit 
several third grade students at SDN Benteng 3, Sukabumi City, West Java (Alamsyah, 2020). Second, violence against minors has occurred again in Lembata Regency, East Nusa Tenggara Province. It is known that an elementary school teacher with the initials AIH beat one of his students with the initials AW (8), a 3rd grade student. Angelina Nole, AW's parent, said that initially her son went to study with his friends at AIH's house. During the learning process, AW and some of his classmates could not do the questions given by AIH. Because he could not do the problem, the AIH teacher immediately hit AW (8) using a screwdriver right on his head (Florespedia.com, 2021). Third, there were five students who were subjected to violent treatment by a teacher at a senior high school in Bekasi, West Java. Allegedly, they were beaten for not wearing a belt and being late for school. The majority of teachers in various schools often use physical and verbal violence in educating and disciplining their students (Febriansyah, 2020).

With the various phenomena of violence in schools or the learning process, it should be a reflection for all parties, especially teachers at every level of education to actively participate in preventing such incidents from happening again. This active role can be carried out by conducting classroom management that is able to provide a sense of security, comfort and conducive to the ongoing learning process. And so, if it is done since early childhood education or also basic education, it can certainly provide a solid foundation for every student so that they can always act based on moral nobility and not harm others.

With that condition, it is necessary to make conceptual mapping of the teacher role in MI for realizing child-friendly classroom management. From that concept can make it easier for teachers to get alternative steps, even though they are still at an early and simple level, to utilize their competencies (pedagogy, personality, social, professional) managing the class towards child friendly.

\section{RESEARCH METHOD}

The method of this research is using literature study by case study in online mass media, reviewing books, literature, notes, and various reports related to classroom management, teacher competence and child-friendly classes. This is because from the three main concepts, a child-friendly classroom management design can be drawn up. And the analysis is using the content analysis; by process of selecting, comparing, combining, and sorting the three main concepts (classroom management, teacher competence and child-friendly classes), until the concept of the role of teachers at MI in managing the class towards being childfriendly is found. 


\section{FINDINGS AND DISCUSSION}

\section{A. Child Friendly Classroom Management}

Teachers have a variety of roles in the classroom or in the learning process. One of the important roles for a teacher in the classroom is to be a manager for the class. Robert J. Marzano stated that the teacher has a variety of distinctive roles in the classroom, but the most important is as a manager. This is because an effective teaching and learning cannot be managed in a poorly managed classroom. If students cannot be orderly and obey the rules, it will create chaos in the classroom, so teachers and students will be in an uncomfortable position. Even this can have an impact on the success of the learning process carried out. On the other hand, well-managed classrooms create good conditions for learning. But a well-managed class certainly doesn't just appear, it takes a lot of effort to create it. And the party most responsible for creating it is the teacher in the class (Robert J. Marzano, Jana S. Marzano, 2003).

This statement shows that the teacher's role as a manager for the class is the important role. So, it needs to be implemented by every teacher. And Related to the concept of classroom management, there are several definitions:

1. Wilford A. Weber states that classroom management is a complex set of behaviors that teachers use to build and maintain classroom conditions that enable students to achieve their instructional goals efficiently and realize ideal conditions in learning (Surjana, 2004).

2. Suharsimi Arikunto states that classroom management is an effort carried out by the person in charge of teaching and learning activities or those who help with the aim of achieving optimal conditions so that learning activities can be carried out as expected (Arikunto, 1992).

3. Ahmad Rohani states that class management is referring to activities that create and maintain optimal conditions for the learning process (report development, cessation of student behavior that distorts class attention, rewards for punctuality, completion of tasks by setting appropriate group norms). productive and so on) (Rohani, 2004).

4. Syaiful Bahri Djamarah states that classroom management is an effort to utilize the potential of the existing class as optimally as possible to support the educational interaction process to achieve learning objectives (Djamarah, 2000).

From these various definitions, it can be concluded that what is meant by classroom management in this case is the entire effort of the teacher in creating and maintaining optimal conditions for the learning process to occur so as to achieve the expected learning objectives. The management effort is of course related to the management of students and the physical management of the class

40 Print - ISSN: 2443-0021

Online - ISSN: 2716-4136 
which includes the infrastructure in the classroom. In addition, the elements that exist in management in general (planning, organizing, directing, and supervising) are inherent in efforts to create and maintain these optimal conditions.

One of the alternative efforts in creating and maintaining these optimal conditions is to include a child-friendly element in classroom management. In this case what is meant by child-friendly elements are elements that support the growth and development of children's potential, protected from acts of violence and discrimination (Humaidi, 2016). Violence as defined by the World Health Organization (WHO) is the intentional use of physical force or power in the form of threats or actual actions, against oneself, another person or against a group of people/communities, which can cause injury or is likely to be injured. death, psychological distress, loss of certain physical parts or improper physical development (WHO, 2002). And violence against children includes at least four kinds of actions, i.e.: physical violence, sexual violence, emotional violence and neglect (WHO, 2002).

In correlation with that, child-friendly classroom management in this case is intended as the overall effort of the teacher in creating and maintaining optimal conditions for the learning process to occur while considering the protection of the growth and development of the potential of students from acts of violence and discrimination to achieve learning objectives. which are expected. From this child-friendly classroom management will encourage the creation of a learning climate in the classroom that is able to provide broad learning opportunities for students without being afraid, depressed, and threatened, both physically and nonphysically.

\section{B. Teacher at Madrasah Ibtidaiyah}

Madrasah Ibtidaiyah (MI) is a form of formal education unit under the guidance of the Minister of Religion which provides general education with the specificity of Islam at the level of Basic Education (PP No 74 Tahun 2008). At Madrasah Ibtidaiyah, the learning process that takes place cannot be separated from the role of teachers at every level, where teachers who teach lessons at Madrasah Ibtidaiyah are generally referred to as classroom teachers (Guru Kelas), namely teachers who have a workload of teaching at least 1 (one) group in 1 (one) full week in one basic education unit, this is in accordance with the regulations related to the Direktorat Jendral Peningkatan Mutu Pendidik dan Tenaga Kependidikan Departemen Pendidikan Nasional Tahun 2009, especially part II Tugas Guru huruf E.

While the academic qualification to become a classroom teacher is to have a minimum educational academic qualification of diploma four (D-IV) or bachelor 
(S1) in the field of education in SD/MI (D-IV/S1 PGSD/PGMI) or psychology obtained from the study program accredited. As for the core competencies of classroom teachers in Elementary Schools/Madrasa Ibtidayyah, based on the regulation, it can be described as follows (Permendiknas No 16 Tahun 2007):

First, Pedagogical Competence, include mastering the characteristics of students from the physical, moral, social, cultural, emotional, and intellectual aspects, mastering learning theory and educational learning principles, understand the principles of curriculum development, organizing educational learning, utilizing information and communication technology for learning purposes. Namely by utilizing information and communication technology in learning, facilitate the development of the potential of students to actualize their various potentials, communicate effectively, empathically, and politely with students, conducting assessments and evaluations of learning processes and outcomes, utilize the results of the assessment and evaluation for the benefit of learning, take reflective action to improve the quality of learning.

Second, Personal Competence, include act in accordance with Indonesian national religious, legal, social, and cultural norms, presenting oneself as an honest person, with noble character, and an example for students and the community, present yourself as a person who is steady, stable, mature, wise, and authoritative, demonstrate work ethic, high responsibility, pride in being a teacher, and self-confidence.

Third, Social Competence, include: become inclusive, act objectively, and not discriminate because of considerations of gender, religion, race, physical condition, family background, and socioeconomic status, communicate effectively, empathically, and politely with fellow educators, education staff, parents, and the community, adapt to the place of duty throughout the territory of the Republic of Indonesia which has socio-cultural diversity, Communicate with the professional community itself and other professions orally and in writing or in other forms.

Fourth, Professional Competence, include: mastering the material, structure, concept, and scientific mindset that supports the subjects taught, mastering the competency standards and basic competencies of the subjects/fields of development being taught, develop creatively guided learning materials, develop professionalism in a sustainable manner by taking reflective actions, utilize information and communication technology to communicate and develop themselves.

From the requirements related to academic qualifications and competencies that must be possessed by class teachers at MI, it shows that the task of being a

42 Print - ISSN: 2443-0021

Online - ISSN: 2716-4136 
class teacher is not something that is easy and light to carry out, especially class teachers also have a workload of full teaching at least 1 (one) class a week.

However, if the main task is carried out with full responsibility and sincerity, it will be carried out properly and as expected. So that the role of class teachers at MI can run optimally in determining the success of students to follow the learning process in class. In addition, students will get adequate supplies and have the readiness to take part in the learning process at the next higher level. Therefore, it is not surprising that the teaching profession has a best position and gets a high degree given by Allah SWT (M.Shabir, 2015).

\section{The Role of Teacher to Manage the Classroom Towards Child Friendly}

Every school or classroom has something special and unique-not the same as the others. This is also stated by John Shindler that every school and people in the class have a peculiarity or uniqueness. In it has its own nuance, rhythm and path (Shindler, 2015). From this, it shows that the process of classroom management should not be made same, even though it is in one school. This means that every teacher in each class of Madrasah Ibtidaiyah, should carry out classroom management according to their respective abilities and capacities towards achieving the expected goals.

From a various literature source, it can be concluded that the role of Madrasah Ibtidaiyah teachers in classroom management towards being childfriendly can be achieved by basing it on two main points of activity; manage the student and the facilities of class. In more detail, it can be described as follows:

1. Manage the student

a. Arrange the child-friendly learning plans

Planning in this case generally involves all matters related to the learning process that will be carried out by the teacher in the classroom. Meanwhile, specifically, it concerns the Learning Implementation Plan (RPP) prepared by the teacher. The regulation in regarding the simplification of RPP, it is stated that the core components in the RPP consist of three parts; Learning Objectives, Learning Steps and Learning Assessment (Surat Edaran Menteri Pendidikan Dan Kebudayaan No 14 Tahun 2019). The preparation of lesson plans is the main guide for teachers in carrying out learning. If the Learning Implementation Plan (RPP) is prepared in a child-friendly manner, then the learning process will be very likely to run and occur in a child-friendly manner, and vice versa. So, the effort to develop a child-friendly learning plan is carried out by, first, reviewing $\mathrm{KI} / \mathrm{KD}$ and the material to be taught, especially in accordance with Peraturan Mendikbud 37 of 2018. Second, choosing 
learning methods and strategies that allow each child's potential to develop optimally. Third, arrange the steps of learning activities by considering the creation of a child-friendly learning atmosphere, such as: the opportunity for students to explore abilities, express opinions, or ideas, learn from various sources or learning materials, ensure a sense of security when students make mistakes. Fourth, conduct an assessment to measure the individual abilities of students, specifically covering three domains, namely attitudes, knowledge, and skills. The results of the assessment as much as possible do not compare the abilities between students with the aim of judging abilities, for example: students who cannot be said to be lazy, do not listen to the teacher's explanations or other words that allow students to be not confident in their abilities. And if comparing the abilities between students is done more to provide motivation and encouragement so that students are always willing to compete for achievement, not because of pressure and threats.

b. Organize students in the learning process with child-friendly rules or codes of ethics.

The rules or code of ethics for each student in classroom learning are prepared by considering the age and stage of development of the students, not just rigid and black and white (as is) rules. This is important, because at the age of students at the MI level, it is very possible in early grades, such as grades 1 and 2, to still be carried away with what was in the previous learning environment, namely when in kindergarten, or even from his family environment. So that the wise and wise attitude of a teacher will provide opportunities for students to understand and apply the code of ethics as well as possible, not because of threats or sanctions that will make students feel ashamed and not confident.

In addition, it is also important for teachers during the implementation of the learning process in the classroom to provide training for students with the same treatment. Because if it is not done, it is possible that it can lead to a different understanding for each student, for example: those who are asked to do assignments in the future are only students whose academic abilities are good, while those whose academic abilities are ordinary or maybe even low are never asked to work on assignments from their peers. teacher, and vice versa. So, if left unchecked, students whose academics will be more confident, while their academic abilities are ordinary or maybe even low, will be increasingly embarrassed to explore their abilities and are afraid to make mistakes in learning. Even Robert T. Tauber in his book Classroom Management; Sound Theory and Effective 
Practice states: too often teachers give responsibility only to students who have demonstrated that they are responsible (Tauber, 2007).

c. Provide direction to students in the learning process according to their capacity/potential and level of development.

Directing is intended as a teacher activity in providing input and direction to students during the learning process so that students are always focused and clear in participating in learning. Guidance is carried out by adjusting the capacity/potential and level of development of students, for example in grades 1, 2 and 3 in MI it is given with real explanations or through image media to make it easy for students to understand. Meanwhile, for grades 4,5 and 6, explanations are verbal (abstract) and do not always use image media. Directions are important so that students understand the purpose of the learning process carried out and how to achieve the goals, including what the learning process will be like.

d. Carry out control or supervision over the course of learning in class by paying attention to the circumstances and potential of students

Supervision of the learning process carried out is important to do. This can be evidence that the teacher has a concern and is responsive to any events or certain things that occur during the learning process. For example, the teacher approaches and provides input to students who seem less focused in following the learning process, the teacher gives advice and even reprimands with good sentences to students who seem to disturb their friends who are studying or doing assignments.

If this is not done properly, it will bring a negative change in the atmosphere in the learning process. For example: first, the teacher is indifferent or allows students who seem less focused in participating in the learning process. Second, the teacher does not respond to questions, ideas or ideas conveyed by students. Third, teachers often give punishment, both physical and non-physical to students who violate class rules, including when there are students who disturb their friends during the learning process.

With the supervision process carried out by considering the potential and rights of children, the learning process carried out can be more directed and achieve the expected goal. 
2. Manage the facilities of class

a. Arrange teacher desks and chairs for students

The arrangement of the teacher's desk and student desk chairs needs to be done by the teacher. This is intended to be able to support the learning process effectively. The arrangement of the teacher's desk and student desk chairs can be done according to the learning materials including KI and KD in it. For example, student tables and chairs are arranged with various variations, i.e.:

1) In the first and second hours, the students' desks and chairs are arranged in a $\mathrm{U}$ (U shape) model/formation.

2) At the third and fourth hours, the student tables and chairs are arranged in a team style model/formation.

3) At the fifth and sixth hours, the student desks are arranged in a conference table model/formation.

With a variety of models for arranging teacher desks and chairs for students by the teacher, the teacher will be able to have a positive impact such as eliminating boredom and students' attention to the material presented will be more focused.

b. Set the classroom furniture

The furniture in the classroom needs to be arranged in such a way that it can function optimally. The furniture includes first cupboards. The cupboard needs to be placed in a position that does not prevent students from accessing the material presented by the teacher, including not too close to the student's seat. In addition, the wardrobe also needs to be given information, what items can be stored in it and even an inventory list of items stored in the cupboard needs to be made. Second, information boards and class identity boards. Information boards and class identities need to be filled in and the data always updated, so that they do not become mere displays. Third, the display board of students' assignments or work. Boards like this need to be used properly to accommodate all the creativity of students and each student has the same right to display the tasks or work that has been done. Fourth, classroom cleaning tools. Tools such as brooms, dusters and trash bins need to be arranged so that they are easily accessible by every student and are not misused by students as a means of playing. Because if the placement is not arranged in such a way, it can be quickly damaged or misused by students.

c. Arrange student seating positions

The seating position of students needs to be arranged so that students do not feel bored or bored. This can be done by doing various variations, 
including on Mondays, students with attendance numbers 1-8 sit in the front row, 9-16 in the second row, 17-24 in the third row. For Tuesday, students with attendance numbers 9-16 sit in the front row, 17-24 in the second row, 1-8 in the third row, and so on for the following days.

In addition to minimizing boredom, such variations can eliminate the perception that the front seats are only for students with good academic scores, while the rear seats are for students with ordinary or even low academic scores, including students who have the potential to often cause noise. in the classroom. Besides that, this can also eliminate the perception that there are certain students who because of their good academic achievements then get more attention from the teacher or in other words are privileged by the teacher in the classroom.

These are some of the roles that classroom teachers at Madrasah Ibtidaiyah can play in realizing child-friendly classroom management. This role is an alternative to create a fun learning process, free from violence, fear, pressure, or threat to students so that the objectives of the learning carried out can be achieved, especially the development of the potential of students optimally. This role will certainly run optimally if there is support from all stakeholders in Madrasah Ibtidaiyah. So it should be, every stakeholder in Madrasah Ibtidaiyah has the awareness to jointly support teachers in realizing child-friendly classroom management.

\section{CONCLUSION}

Several things related to the role of MI teachers in managing the classroom towards being child-friendly can be described as follows: first, the management of child-friendly classes in this case is the overall effort of the teacher in creating and maintaining optimal conditions for the learning process to occur while maintaining the protection of growth and development. potential of students from acts of violence and discrimination to achieve the expected learning objectives.

The role of teachers at Madrasah Ibtidaiyah in realizing child-friendly classroom management can be achieved by basing it on two main points of activity, namely: managing students, especially in planning child-friendly learning, organizing students in the learning process with friendly rules or codes of ethics. children, providing direction to participants in the learning process according to their capacity/potential and development, as well as controlling or supervising classroom learning by considering the circumstances and potential of students. In addition, the management of classroom facilities, especially in 
arranging teacher desks and chairs for students, arranging classroom furniture, arranging student seating positions.

The benefits that will be obtained if the teacher manages the class in a childfriendly manner include growing and developing the potential of students without fear, worry and anxiety so that the existing potential can develop optimally. In addition, the learning atmosphere can take place in a conducive and fun way. Meanwhile, if the teacher manages the class in a non-child-friendly manner, it will have an impact, including not optimal development of the potential of students, the class atmosphere is not conducive and the possibility of the emergence of violence in the class is getting higher.

\section{REFERENSI}

Alamsyah, S. (2020). Kasus Guru Pukul Murid di SDN Benteng 3 Sukabumi Berakhir Islah. https://news.detik.com/berita-jawa-barat/d-4876445/kasusguru-pukul-murid-di-sdn-benteng-3-sukabumi-berakhir-islah

Arikunto, S. (1992). Pengelolaan Kelas dan Siswa. CV Rajawali.

Arinanto, S. (2001). Hak Atas Pendidikan Sebagai Hak Asasi Manusia dan Implementasinya Dalam PerspektifProvinsi Nanggroe Aceh Darusslam (NAD).

Djamarah, S. B. (2000). Guru dan Anak Didik Dalam Interaksi Edukatif. Rineka Cipta.

Febriansyah. (2020). Viral Video Guru SMAN di Bekasi Pukul Siswa, KPAI: Polisi Wajib Periksa Pelaku. https://nalar.id/viral-video-guru-sman-dibekasi-pukul-siswa-kpai-polisi-wajib-periksa-pelaku/

Florespedia.com. (2021). Pukul Murid Pakai Obeng, Guru di Lembata Dipolisikan Orang Tua. https://kumparan.com/florespedia/pukul-muridpakai-obeng-guru-di-lembata-dipolisikan-orang-tua-1vCrwebynUJ/full

Humaidi, A. N. S. dan L. (2016). Panduan Sekolah dan Madrasah Ramah Anak. Erlangga.

M.Shabir. (2015). Kedudukan Guru Sebagai Pendidik. Auladuna, 2, 221-232. http://journal.uin-alauddin.ac.id/index.php/auladuna/article/view/878

Permendiknas No 16 Tahun 2007.

PP No 74 Tahun 2008.

Prasetyono, A. P. (2018). Menyelaraskan Kebijakan Pembangunan IPTEK. https://ristekdikti.go.id/menyelaraskan-kebijakan-pembangunan-iptek/

Robert J. Marzano, Jana S. Marzano, D. J. P. (2003). Classroom Management That Works. ASCD.

$48 \quad$ Print - ISSN: 2443-0021

Online - ISSN: 2716-4136 
Zuri Pamuji

The Role of the Teacher in Madrasah Ibtidaiyah to Manage Class

Towards Child-Friendly

Rohani, A. (2004). Pengelolaan Pengajaran. Rineka Cipta.

Shindler, J. (2015). Tranformative Classroom Management. Jossey Bass.

Surat Edaran Menteri Pendidikan dan Kebudayaan No 14 Tahun 2019.

Surjana, A. (2004). Efektivitas Pengelolaan Kelas. Jurnal Pendidikan Penabur, 2 , $68-81$.

Undang-Undang Sistem Pendidikan Nasional, (2003).

UU Nomor 14 tahun 2005.

WHO. (2002). World report on violence and health.

Yahya, M. S. (2007). Pendidikan Islam dalam Pengembangan Potensi Manusia. Insania, 12, 164-174. https://doi.org/10.24090/insania.v12i2.248 